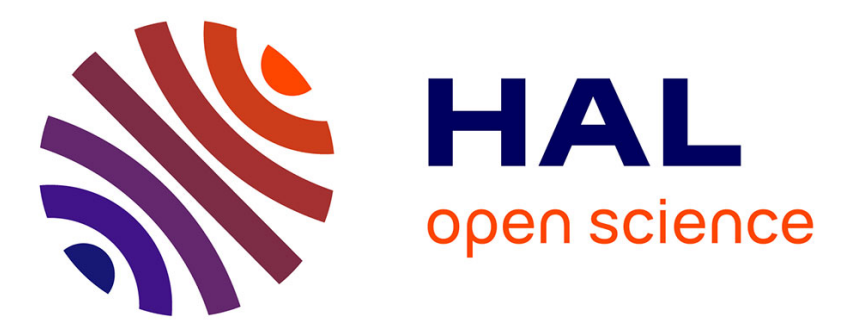

\title{
Geographical and habitat differences in concentrations of copper, zinc and arsenic in eggshells of the Rook in Poland
}

Grzegorz Orlowski, Zbigniew Kasprzykowski, Wojciech Dobicki, Przemyslaw Pokorny, Ryszard Polechoński

\section{To cite this version:}

Grzegorz Orlowski, Zbigniew Kasprzykowski, Wojciech Dobicki, Przemyslaw Pokorny, Ryszard Polechoński. Geographical and habitat differences in concentrations of copper, zinc and arsenic in eggshells of the Rook in Poland. Journal für Ornithologie = Journal of Ornithology, 2009, 151 (2), pp.279-286. 10.1007/s10336-009-0453-8 . hal-00568351

\section{HAL Id: hal-00568351 https://hal.science/hal-00568351}

Submitted on 23 Feb 2011

HAL is a multi-disciplinary open access archive for the deposit and dissemination of scientific research documents, whether they are published or not. The documents may come from teaching and research institutions in France or abroad, or from public or private research centers.
L'archive ouverte pluridisciplinaire HAL, est destinée au dépôt et à la diffusion de documents scientifiques de niveau recherche, publiés ou non, émanant des établissements d'enseignement et de recherche français ou étrangers, des laboratoires publics ou privés. 
Geographical and habitat differences in concentrations of copper, zinc and arsenic in eggshells of the Rook Corvus frugilegus in Poland

Grzegorz Orłowski ${ }^{1 *}$, Zbigniew Kasprzykowski ${ }^{2}$, Wojciech Dobicki ${ }^{3}$, Przemysław Pokorny ${ }^{3}$, Ryszard Polechoński ${ }^{3}$

${ }^{1}$ Institute of Agricultural and Forest Environment, Polish Academy of Sciences, Bukowska 19, 60-809 Poznań, Poland. *Corresponding author (e-mail address: orlog@ poczta.onet.pl); Tel./fax: +48655134253

${ }^{2}$ Department of Ecology and Nature Protection, University of Podlasie, Prusa 12, 08-110 Siedlce, Poland

${ }^{3}$ Department of Limnology and Fishery, Wrocław University of Environmental and Life Sciences, Chełmońskiego 38C, 51-630 Wrocław, Poland

*Corresponding author (e-mail address: orlog@poczta.onet.pl); Tel./fax: +48 655134253

Abstract: Levels of copper, zinc and arsenic were analyzed in rook Corvus frugilegus eggshells from 43 breeding colonies located in different parts of Poland. The average (95\% confidence limit) level of copper was found to be 8.13 (0.64-15.62) ppm, of zinc 13.81 (7.9919.62) ppm and of arsenic 32.57 (25.60-39.54) ppm. The metal concentration levels varied widely in the surveyed shells. In case of copper the difference between extreme values was 90-fold, for zinc 57-fold and for arsenic 36-fold. General linear model (GLM) analysis revealed that copper accumulation in eggshells from urban rookeries was significantly higher than in those from villages (average (with 95\% c.1.), $19.31 \mathrm{ppm}(4.57-43.20)$ and $2.74 \mathrm{ppm}$ (2.36-3.12), respectively). In the eggshells of rooks nesting in cities the concentration of zinc was only close to being significantly higher $(P=0.07)$. The arsenic levels in rural and urban colonies were similar. No significant differences were proved for any of the metals between the rookeries located in the areas of intensive (western Poland) and extensive (eastern Poland) agriculture. Compared to other data on the arsenic contamination affecting different biota, including tissues and bird eggs of terrestrial and aquatic animals, the level of this metal in rook eggshells should be regarded as extremely high. It is probably due to the widespread use of pesticides containing arsenic. 
Key words: agricultural contaminants, soil contamination, biomonitoring, trace elements, pesticides, arsenic, bird eggs, rookeries

\section{Introduction}

The rook Corvus frugilegus represents a group of birds strongly associated with agroecosystems, especially in central and eastern Europe where the considerable majority of rooks nest within farmed landscapes. Their diet is mainly based on Coleoptera and cereal grains which are found in the arable fields (Jabłoński 1979, reviews in Cramp 1998, Kasprzykowski 2003, Orłowski et al. 2009). The strong link between the rook and the arable areas may make the species prone to the adverse or even lethal effects of agricultural-related contaminants, especially pesticides and heavy metals (Malmberg 1973). In spite of the fact that the rook is a common species in central and western Europe (Brenchley and Tahon 1997), the ecotoxicological studies were conducted only in the distant past and concerned merely single or at most several rookeries (reviewed in Beyerbach et al. 1987).

Moreover it is worth underlining that there is a shortage of studies investigating the level of contamination among different populations within the same species in the terms of ecotoxicological research. Revolutionary changes in the intensification of agricultural productivity including introduction of new fertilizing methods and the application of technologically advanced pesticides imply an acute need to determine the level of contamination in the tissues of species strongly linked with agricultural areas. It is also of crucial importance to compare birds`contamination with that of the environment.

The main source of contamination of agricultural areas with heavy metals, including copper $(\mathrm{Cu})$ and zinc $(\mathrm{Zn})$ are commonly used manure and slurry (Dach and Starmans 2005). An increase in livestock numbers and faulty utilization of huge amounts of animal faeces containing chemical remnants of food additives (mainly copper and zinc) are regarded as the main threats connected with the intensification of agricultural productivity in Europe (de Vries et al. 2002, Dach and Starmans 2005). The contamination of agricultural areas with arsenic (As) is linked to the massive use of pesticides containing this metal. It is believed that introducing of first arsenical pesticides began in the end of the 19th century (Murphy and Aucott 1998, Peryea 1998, review in Mandal and Suzuki 2002). Copper (as copper hydroxide and copper sulfate) is similarly applied in many different kinds of pesticides (Epstein and 
Bassein 2001) while arsenic appears nowadays mainly in the form of monosodium methanearsonate (MSMA), monomethylarsocic acid (MMAV) and dimethylarsinic acid (DMAV) from which herbicides, including defoliants, are manufactured. Two other arsenic compounds (lead arsenate and copper acetoarsenite), in use for a considerably longer time, are the base for insecticide production. Arsenic and its derivatives affect biota and human health and their biogeochemical cycles are currently being studied in many countries of the world (Mandal and Suzuki 2002, Sierra-Alvarez et al. 2006).

The metals can permeate the birds`organisms through ingestion (Best and Fisher 1982, Schafer et al. 1983). In Coleoptera, constituting the main rook's prey (Orlowski et al. 2009), after pesticide application the level of arsenic may be very high (Morrissey et al. 2007, Orlowski et al. 2009). Females of birds can get rid of the surplus of the heavy metals by eliminating it through the egg shells (Burger 1994, Dauwe et al. 2005). Some pesticides contribute to the accumulation of the heavy metals in bird tissues, e.g. addition of DDE to the diet of black duck Anas rubripes resulted in an increased copper content in the eggshells (Longcore et al. 1972). According to Dauwe et al. (1999) the eggshell is a suitable indicator for heavy metal contamination, especially in case of arsenic, the level of which was higher in eggshells from the contaminated breeding sites. However, the content of metals in eggs varies from species to species and contamination level is different in the shell and in the content of the egg itself (Burger 1994, Morera et al., 1997, Dauve et al. 1999, Mora 2003). Mora (2003) proved a higher arsenic and copper concentration in the eggshells of small Northern American passerines than in the egg contents while in the case of zinc it was lower. Morera et al. (1997) found lower concentration of zinc and copper in Audouin's gull Larus audouinii egg content. However, Swaileh and Sansur (2006) showed that the concentration of copper and zinc in the eggshell and the egg content of house sparrow Passer domesticus were highly correlated.

The aim of this study was to define the level of the three metals (arsenic, copper and zinc) in the eggshells of rooks nesting in Poland. The study draws a comparison in the metal concentration depending on the geographical position (western vs. eastern Poland) and rookery location (rural vs. urban habitat). Current growth in intensification of agricultural production and the differences between western and eastern Poland (i.e. intensive vs. extensive agriculture) were expected to cause different concentration of agriculture-related contaminants, e.g. the level of arsenic seemed likely to be higher in colonies of the western part of the country. Due to the high production of manure in rural areas we expected the concentration of zinc and copper there to be higher than in urban rookeries. 


\section{Material and methods}

The rook eggshells were collected in spring 2005 in 43 rookeries (number of nests in particular colonies ranged from 5 to 480) located in Poland. The shells were collected from the ground under nests. The material was then deprived of membrane remnants and visible external dirt and stored in glass containers so that the analysis of the metal concentration levels in samples from different geographical locations, with varying production intensity and habitat type, could be made.

During the analysis of the results the division between the colonies located in the west (intensive agriculture) and east (extensive agriculture) Poland as well as between urban and rural sites was applied. The river Vistula played the main role in the geographical division into east and west as it flows through the middle of Poland (Fig.1). This division was made in relation to a set of eight agricultural statistics i.e. the number of farm workers per $\mathrm{km}$, milking capacity and livestock number, mineral fertilization intensity, the number of available tractors and harvesters, the cereal crops area, and the farm size (acc. to Chylarecki et al. 2006). The basis for the division into colonies located in villages $(n=29)$ and cities $(n=14)$ was the number of inhabitants in each locality. The number of 50000 people was taken as the threshold for defining a city (after Orłowski and Czapulak 2007).

Due to a rather small amount of shells successfully collected in some rookeries, the metal concentration for each colony was determined using just two different shells or their fragments. In practice, the big pieces of shells were used, to ensure that they came from different eggs. Prior to the chemical analysis all eggshells were rinsed twice with water with detergent and air dried. They were then mineralized in the mixture of nitric and hypochloric acid in the high-pressure microwave MARS-5 digestion system (CEM, USA). The metal content was determined by means of atomic-absorption spectroscopy in Varian SpectrAA FS220. The measurement process was validated with the aid of reference material, DOLT-2 (fish liver) and DORM-2 (fish muscles), provided by the National Research Council of Canada Institute for National Measurement. The precision of method, understood as the degree of conformity between the results of multiple analyses performed on the same sample, corresponded to $5 \%$ (relative standard deviation, RSD). Reference values amounted to $25.8 \pm$ $1.1,85.8 \pm 2.5$ and $16.6 \pm 1.1 \mathrm{ppm}$ for copper, zinc and arsenic respectively; whilst the average determined values ( 6 measurements in $0.9 \mathrm{~g}$ samples) were $25.24 \pm 0.25,87.20 \pm$ 0.35 and $17.6 \pm 1.0 \mathrm{ppm}$ respectively. All concentrations of metals were expressed in 
milligrams per kilogram (mg kg-1 or parts per million; ppm) of dry mass (d.w.) with the accuracy of two decimal points.

Statistical analysis of the collected material was conducted with the help of Statistica 7.0 (StatSoft 2006) and Excel software. The statistical significance level was 0.05. The differences between heavy metal concentrations of specified data sets were tested by general linear model (GLM) analysis. In GLM analysis two values of metal concentration from each rookery were used. Combined effect between the levels of metals, taking into consideration an interaction between geographic and habitat divisions, was analyzed in GLM (StatSoft, 2006) resulting in Wilks $\lambda$. Spearman rank correlation coefficient $\left(r_{s}\right)$ was used to define relationships between the analysed metals. Data are presented as means with $95 \%$ confidence limit (c.1.).

3. Results

Average (95\% c.l.) concentration of copper amounted to $8.13(0.64-15.62) \mathrm{ppm}$, zinc 13.81 (7.99-19.62) ppm and arsenic 32.57 (25.60-39.54) ppm. The levels of metal concentration in the shells collected in the surveyed colonies varied enormously. The difference between extreme values was 90-fold for copper, 57-fold for zinc and 36-fold for arsenic (Appendix 1). Extremely high concentrations of particular metals were obtained only in a few colonies. In case of copper such extremely high levels ( $>8 \mathrm{ppm}$ ) were measured in three rookeries located in two cities (633 000 and 71000 inhabitants) in western Poland (Wrocław - two rookeries and Głogów; Appendix 1). In the other 40 (93\%) rookeries the concentration of copper did not exceed $7.60 \mathrm{ppm}$. Similar results were obtained for zinc, the concentration of which in 40 rookeries did not exceed $20.38 \mathrm{ppm}$ and extreme values were measured only in three rookeries in western Poland (Appendix 1). Arsenic concentration was more stable, and despite the lack of extremely high values, in 30 (70\%) rookeries a very high concentration of over $20 \mathrm{ppm}$ was recorded.

Statistically significant correlations among metal concentrations were recorded only in the case of zinc and copper (Spearman rank correlation coefficient, $\mathrm{r}_{\mathrm{s}}=0.22, P=0.04$ ). For the other pairs of metals these relationships were insignificant $\left(\mathrm{Cu}\right.$ and $\mathrm{As}, \mathrm{r}_{\mathrm{s}}=-0.16, P=$ 0.14; As and $\left.\mathrm{Zn}, \mathrm{r}_{\mathrm{s}}=0.10, P=0.37\right)$.

The copper accumulation in eggshells of town-nesting rooks was significantly (7-fold) higher than in villages (Table 1). The concentration of zinc was also 2-fold higher there than in villages, however this difference was only close to being statistically significant $(P=0.07)$. 
Arsenic levels were similar in both rural and urban colonies. No significant differences were proved for any of the metals between the colonies located in the areas of intensive (western Poland) and extensive (eastern Poland) agriculture (Table 1).

An analysis of combined effect among the levels of metals in the surveyed rookeries, after taking into consideration their geographical and habitat division, showed statistically significant interaction only in case of copper (GLM: Wilks $\lambda=0.89, \mathrm{df}=83, P=0.01$ ). For the rest of metals the combined effects were not statistically significant (GLM for Zn: Wilks $\lambda$ $=0.95, \mathrm{df}=83, P=0.16$; GLM for As: Wilks $\lambda=0.97, \mathrm{df}=83, P=0.26$ ).

\section{Discussion}

The arsenic concentration in the eggshells of the rook in Poland exceeded 20 ppm d.w. (see Appendix 1) in 30 out of 43 surveyed rookeries. Compared to the data on the level of contamination with arsenic for biota, including tissues of terrestrial and aquatic animals and bird eggs (Dauwe et al. 1999, Kubota et al. 2002, Mandal and Suzuki 2002, Mora 2003, Dauwe et al. 2005), the level of this metal should be regarded as extremely high. High level of arsenic in the rook eggshells should be linked with its long-term accumulation in soil as a result of using pesticides containing this metal (Murphy and Aucott 1998, Peryea 1998). The high usage of pesticides in Poland (total weight of insecticides, fungicides, rodenticides and others) has appeared to be stable since the beginning of 1960s (in 1960, $45013^{-3} \mathrm{~kg}$; in 2005 , $44130^{-3} \mathrm{~kg}$; GUS 1970-2007). However, it is difficult to relate pesticide usage to the absolute amount of active ingredients (currently used determiner), as the total usage of pesticides was defined by using of different determiner in the past. This is the reason why data on the combined weight of the pesticides used in 1960 in Poland is incomparably higher than the statistics from western Europe, where an almost 10-fold increase of pesticide use was recorded between 1957 and 1995. It was measured there in relation to the amount of active ingredients (review in Sotherton and Holland 2003).

Mora (2003) established an average arsenic concentration ( \pm SD) in the shells of two species of North American woodland passerines at $2.1( \pm 0.4)$ and $1.3( \pm 0.2)$ ppm d.w. The level of arsenic in the shells of great tit Parus major and blue tit P. caeruleus living in contaminated areas in Belgium did not exceed $4.2 \mathrm{ppm}$ (Dauwe et al. 1999), while arsenic concentration in tissues and egg contents in black-tailed gull Larus crassirostris from Japan did not exceed 2.91 ppm d.w. (Kubota et al. 2002). According to data of Evry et al. (1999) the 
arsenic concentration in birds' of prey organs originating from Britain did not exceed 0.346 ppm d.w. while the highest concentration described in literature (56 ppm d.w and $40.6 \mathrm{ppm}$ d.w.) was found in the liver of a dead osprey Pandion haliaetus (Wiemeyer et al. 1980) and brown-headed cowbird Molothrus ater (NAS 1977). According to Mandal and Suzuki (2002) an average level of arsenic measured in freshwater fish amounts to $0.54 \mathrm{ppm}$ in wet weight, although some values reach as much as $77 \mathrm{ppm}$. Equally high levels of arsenic in natural environment were recorded only in soil, especially in areas of arsenic geological origin or in regions heavily contaminated by industry or agriculture (Mandal and Suzuki 2002, Hossain 2006). The arsenic level in unpolluted soils from various countries ranged from 0.1 to 40 ppm; in some areas contaminated by pesticides or mining activity rising to between 57 and 2470 ppm (review in Hossain 2006) and in south-western Poland it reached up to 800 ppm (WIOŚ 2008).

Contrary to arsenic, concentrations of zinc and copper in rook eggshells in Poland (excluding three extreme values for both metals; see Appendix 1) were not considerably different from the results obtained by other scientists studying the level of these metals in eggshells. The average level of copper and zinc in eggshells of two small woodland passerines from Arizona amounted to 3.0 and $6.2 \mathrm{ppm}(\mathrm{Cu})$ and 9.5 and $46.2 \mathrm{ppm}(\mathrm{Zn})$ (Mora et al. 2003). The average concentration of copper in eggshells of house sparrow originating from Middle East amounted to $1.0 \mathrm{ppm}$ (range: 0.9-1.2 ppm) and zinc - $20.0 \mathrm{ppm}$ (range: 14.3-25.5 ppm) (Swaileh and Sansur 2006). The average level of copper and zinc in shells of great and blue tit living in contaminated area in Belgium was respectively $3.2 \mathrm{ppm}$ and 32 ppm (Dauwe et al. 1999). The mean level of copper in eggshells of grey heron Ardea cinerea, night heron Nycticorax nycticorax and Audouin`s gull nesting in Turkey amounted to 6.75 and $1.37 \mathrm{ppm}$ and in case of the last mentioned species (data for two breeding colonies), 1.85 and 10.20 ppm (Ayas 2007, Ayas et al. 2008). However, the eggshells of grey heron nesting in three different colonies in Poland in unpolluted areas had an average level of copper ranging between 4.13 and $5.27 \mathrm{ppm}$, and zinc from 1.62 to $2.24 \mathrm{ppm}$ (Dmowski 1999). In two oceanic species such as short-tailed albatross Phoebastria albatrus and black-footed albatross, Ph. nigripes, found in Japan, the average copper concentration in eggshells was 0.77-0.78 ppm and zinc 3.39-5.61 ppm (Ikemoto et al. 2005).

The significantly higher level of copper in eggshells of the rook from the colonies located in towns results mainly from its extremely high concentration in three rookeries in south-western Poland (see Appendix 1). After excluding these values the copper levels in both habitats are very similar (villages, $2.74 \mathrm{ppm}$; towns, $3.08 \mathrm{ppm}$ ). An extremely high copper 
concentration in three rookeries in south-western Poland was probably related to the geology of the area where some intensively exploited copper deposits are located. The average level of copper in rook eggshells in Poland (with the exception of three extreme values) was found to be 2.83 (min-max $=1.67-7.21) \mathrm{ppm}$ (see Appendix 1). It was considerably lower than the minimal value established as the lowest indicator (indices on five class scale from 0 to 5 $\geq 100 \mathrm{ppm}$ ) of soil contamination in Poland (IOŚ 2003). A similar picture emerges for zinc, as its level in eggshells after excluding three extreme values was found to be $9.41 \mathrm{ppm}$ (min-max $=1.98-20.38)$. Such concentration is also considerably lower than the minimal value (50 ppm) reported as the lowest indicator of soil contamination in Poland (IOS 2003). The three extremely high values of zinc concentration were noted in the heavily industrialized cities in western Poland. It proves that the contamination does not originate from agriculture, especially if we note that the level of zinc in the soil exceeded the highest contamination class ( $\geq 500$ ppm; acc. data presented by WIOŚ 2008).

The extremely high level of arsenic in rook eggshells in Poland indicates that this metal can be regarded as a potential threat to the proper growth and development of birds organisms. The lack of confirmation of preliminary expectations about the higher metal concentration in the eggshells of birds nesting in western Poland may result from the species` biology and it may relate to the fact of wintering away from their breeding areas. Rooks originating from Poland winter mainly in western Europe where they spend several months (Gromadzki and Mokwa 2005). Hence the contamination level in eggshells of rook and other migratory bird species may be linked to a lesser degree with the contamination around nesting sites than in resident species (Dmowski 1999). However, studies conducted on domesticated hens indicated that bioaccumulation and excretion of arsenic is fast - birds which were being fed on food with high content of arsenic (up to $100 \mathrm{ppm}$ ) reached maximum concentration in the sixth week, while the excretion from the organism was completed up to two weeks after the experiment (Daghir and Nariri 1977). The two main arsenic derivatives which have been applied as pesticides (arsenobetaine and dimethylarsinic acid) can permeate to the inside of the bird eggs and the first mentioned compound may account for as much as $95 \%$ of the total arsenic content (Kubota et al. 2002). Arsenic accumulation in nestlings` tissues may lead to weight reduction; however no influence was reported on hatching success or on teratogenic activities (Stanley et al. 1994). According to Camardese et al. (1990) an extremely high arsenic concentration (up to $430 \mathrm{ppm}$ d.w.) in the vegetable food of mallard Anas platyrhynchos nestlings increased nesting time and decreased the overall nestlings growth. It must be emphasized that despite the methodical inconveniences with assessment of local 
contamination levels due to the rook migration cycle, the species' eggshells should be used as a tool in monitoring of agricultural contamination, especially pesticides and their remnants. Constant threat of heavy agricultural contamination implies an acute need for further studies on defining relations between its level and amount in different tissues and the nestlings` condition.

\section{Zusammenfassung}

\section{Geographische und Habitatunterschiede in den Konzentrationen von Kupfer, Zink und} Arsen in Eierschalen der Saatkrähe Corvus frugilegus in Polen

Der Gehalt von Kupfer, Zink und Arsen wurde in Eierschalen der Saatkrähe Corvus frugilegus aus 43 in verschiedenen Teilen Polens gelegenen Brutkolonien analysiert. Der durchschnittliche (95\%-Konfidenzintervall) Gehalt von Kupfer betrug 8,13 (0,64-15,62) ppm, der von Zink 13,81 (7,99-19,62) ppm und der von Arsen 32,57 (25,60-39,54) ppm. Die Metallkonzentrationen in den untersuchten Eierschalen schwankten stark. Im Falle von Kupfer bestand ein 90-facher Unterschied zwischen den Extremwerten, für Zink war er 57fach und für Arsen 36-fach. Eine allgemeine lineare Modellanalyse zeigte, dass die Anreicherung von Kupfer in Eierschalen aus Krähenhorsten in Städten signifikant höher war als aus Horsten in Dörfern (Mittelwerte (95\%-Konfidenzintervall) 19,31 ppm (4,57-43,20) bzw. 2,74 ppm (2,36-3,12)). In den Eierschalen von in Städten nistenden Saatkrähen war die Zinkkonzentration gerade eben nicht signifikant höher $(\mathrm{P}=0,07)$. Die Arsenkonzentrationen in Kolonien auf dem Land und in der Stadt waren ähnlich. Für keines der Metalle bestanden signifikante Konzentrationsunterschiede zwischen Horsten in Regionen intensiven (Westpolen) und extensiven (Ostpolen) Ackerbaus. Im Vergleich mit anderen Daten zur Arsenbelastung verschiedener Biota, einschließlich der Gewebe und Eier landlebender und aquatischer Vögel, sollte der Gehalt dieses Metalls in den Eierschalen von Saatkrähen als extrem hoch angesehen werden. Dies ist wahrscheinlich auf den weitverbreiteten Gebrauch von arsenhaltigen Pestiziden zurückzuführen.

\section{Acknowledgements}

We are grateful to A. Wuczyński, P.T. Dolata, K. Kujawa, R. Kruszyk, J. Pietrowiak, M. Rachel, T. Mazgajski, R. Piekarski, S. Kuźniak, S. Jędrzejewski, A. Sokołowska, T. Wilżak, 
J. Ratajczak, P. Tryjanowski, T. Stawarczyk, M. Słupek, M and U. Martini and Management of Landscape Parks in Sieradz for participating in the ecotoxicological study of the rook in Poland. We would also like to thank M. Sęk for checking the English version of the text.

\section{References}

Ayas Z (2007) Trace element residues in eggshells of grey heron (Ardea cinerea) and blackcrowned night heron (Nycticorax nycticorax) from Nallihan Bird Paradise, Ankara-Turkey. Ecotoxicology 16:1573-3017.

Ayas Z, Celikkan H, Aksu ML (2008) Lead $(\mathrm{Pb})$ and Copper $(\mathrm{Cu})$ Concentration in the Eggshells of Audouin's Gulls (Larus audouinii) in Turkey. Turk J Zool 32:1-6.

Best LB, Fisher DL (1982) Granular insecticides and birds: factors to be considered in understanding exposure and reducing risk. Environ. Toxicol Chem 11:1495-1508.

Beyerbach M, Büthe A, Heidmann WA, Dettmer R, Knüwer H (1987) Chlorierte Kohlenwasserstoffe in Eiern und Lebern von Saatkrähen (Corvus frugilegus) aus niedersächsichen Brutkolonien. J Ornithol 128:277-290.

Brenchley, A., Tahon, J. 1997. Rook Corvus frugilegus. In: Hagemeijer E. J. H., Blair M J. (Eds.) The EBCC Atlas of European Breeding Birds: Their Distribution and Abundance. T \& AD Poyser, London.

Burger J (2004) Heavy metals in avian eggshells: another excretion method. J Toxicol Environ Health 41:207-20.

Camardese, M.B., Hoffman, D.J., LeCaptain, L.J., Pendleton, G.W., 1990. Effects of arsenate on growth and physiology in mallard ducklings. Environ. Toxicol. Chem. 9:785-794.

Chylarecki P., Jawińska D., Kuczyński L. 2006. Common Breeding Bird Monitoring in Poland: Annual report 2003-2004. Polish Society for the Protection of Birds, Warsaw, Poland. 30 pp. (available: www.otop.pl)

Cramp S. (ed) (1998) The Complete Birds of the Western Palearctic on CD-ROM. Oxford Univ. Press.

Dach J, Starmans D (2005) Heavy metals balance in Polish and Dutch agronomy: Actual state and previsions for the future. Agric Ecos Environ 107:309-316.

Dauwe T, Janssens E, Bervoets L, Blust R, Eens M (2005) Heavy metal concentrations in female laying great tits (Parus major) and their clutches. Arch Environ Contam Toxicol 49:249-256. 
Dauwe T, Janssens E, Bervoets L, Blust R, Eens M (2004) Relationships between metal concentrations in great tit nestlings and their environment and food. Environ Pollut 131:373380.

Dauve T, Bervoets L, Blust R, Pinxten R, Eens M (1999) Are eggshells and egg contents of great and blue tits suitable as indicators of heavy metal pollution? Belg J Zool 129:439-447.

Daghir NJ, Nariri NN (1977) Determination of total As residues in chicken eggs. J Agric Food Chem 25:1009-1010.

de Vries W, Römkens PF, van Leeuwen T, van Bronswijk JJ (2002) Heavy metals. In: Hagyart PM, Jarvis SC (eds) Agriculture, Hydrology and Water Quality. CAB International Publishing, Oxon. pp 107-132.

Epstein L, Bassein S (2001) Pesticide applications of copper on perennial crops in California, 1993-1998. J Environ Qual 30:1844-1847.

Erry BV, Macnair MR, Meharg AA, Shore RF, Newton I (1999) Arsenic residues in predatory birds from area of Britain with naturally and anthropogenically elevated arsenic levels. Environ Pollut 106:91-95.

Gromadzki M., Mokwa K (2005) Migrations and wintering of the Rook Corvus frugilegus in Poland - analysis based on recoveries. In: Jerzak L, Kavanagh BP, Tryjanowski P (eds) Corvids of Poland. Bogucki Wydawnictwo Naukowe, Poznań. pp 319-331.

GUS (1970-2007). Statistical Yearbook of the Republic of Poland. Wydawnictwo GUS, Warszawa.

Ikemoto T, Kunito T, Tanabe S, Tsurumi M, Sato F, Oka N (2005) Non-destructive monitoring of trace element levels in short-tailed albatrosses (Phoebastria albatrus) and black-footed albatrosses (Phoebastria nigripes) from Torishima Island, Japan, using eggs and blood. Mar Pollut Bull 51:889-895.

IOŚ (2003) The State of Environment in Poland 1996-2001. Inspection for Environmental Protection. Warsaw.

Jabłoński B (1979) Food of the rook, Corvus frugilegus L. in different parts of its territory. Przegląd Zoologiczny 23:67-80. (in Polish)

Hossain MF (2006) Arsenic contamination in Bangladesh - An overview. Agric Ecos Environ 113: $1-16$.

Kasprzykowski Z (2003) Habitat preferences of foraging Rooks Corvus frugilegus during the breeding period in the agricultural landscape of eastern Poland. Acta Ornithol 38:27-31. 
Kubota R, Kunito T, Tanabe S, Ogi H, Shibata Y. (2002) Maternal transfer of arsenic to eggs of black-tailed gull (Larus crassirostris) from Rishiri Island, Japan. Appl Organometal Chem $16: 463-468$.

Longcore JR, Samson FB, Kreitzer JF, Spann JW (1972) Changes in mineral composition of eggshells from black ducks and mallards fed DDE in the diet. Bull Environ Contam Toxicol 6:345-350.

Mandal BK, Suzuki KT (2002) Arsenic round the world: a review. Talanta 58:201-235.

Malmberg T (1973) Pesticides and the rook Corvus frugilegus in Scania, Sweden between 1955 and 1970. Oikos 24:377-387.

Morrissey CA, Albert CA, Dods PL, Cullen WR, Lai VW, Eliot JE (2007) Arsenic accumulation in bark beetles and forest birds occupying mountain pine beetle infested stands treated with monosodium methanearsonate. Environ Sci Technol 41:1494-1500.

Mora M (2003) Heavy metals and metalloids in egg contents and eggshells of passerine birds from Arizona. Environ Poll 125:393-400.

Murphy EA, Aucott M (1998) An assessment of the amount of arsenical pesticide used historically in a geographic area. Sci Total Environ 218:89-101.

Orłowski G, Czapulak A (2007) Different extinction risks of the breeding colonies of Rook Corvus frugilegus in rural and urban areas of SW Poland. Acta Ornithol 42:145-155.

Orłowski G, Kasprzykowski Z, Zawada Z, Kopij G (2009) Stomach content and grit ingestion by Rook Corvus frugilegus nestlings. Ornis Fenn, in press.

Peryea FL (1998) Historical use of lead arsenate insecticides, resulting soil contamination and implications for soil remediation. Proc. 16th World Congress of Soil Science (CD Rom), Montpellier, France. 20-26 Aug. 1998. (available: http://soils.tfrec.wsu.edu/leadhistory.htm)

Schafer EW Jr, Bowlers WA Jr., Hurlbut J (1983) The acute oral toxicity, repellency, and hazard potential of 998 chemicals to one or more species of wild and domestic birds. Arch Environ Contam Toxicol 12:355-382.

Sotherton N, Holland J (2003) Indirect Effects of Pesticides on Farmland Wildlife. In: Hoffman DJ, Barnett A, Rattner G, Burton GA, Cairns J (eds). Handbook of Ecotoxicology, Second Edition. CRC Press, Boca Raton, FL. pp 1173-1192.

Stanley TR, Spann JW, Smith GJ, Rosscoe R (1994) Main and interactive effects of arsenic and selenium on mallard reproduction and duckling growth and survival. Arch Environ Contam Toxicol 26:444-451.

Swaileh KM, Sansur R (2006) Monitoring urban heavy metal pollution using the House Sparrow (Passer domesticus). J Environ Monit 8:209-213. 
StatSoft (2006) Statistica@ (data analysis software system), version 7.1. Tulsa, USA. (www.statsoft.com)

WIOŚ (2008) Ocena stopnia zanieczyszczenia gleb województwa dolnośląskiego w 2007 roku - obszary bezpośrednio zagrożone zanieczyszczeniami. [The assessment of soil contamination level in the Lower Silesia region in 2007 - areas directly threatened by contamination.] Wojewódzki Inspektorat Ochrony Środowiska we Wrocławiu. Wrocław. 88 pp. (available: http://wroclaw.pios.gov.pl/pliki/gleby/ocena_2007.pdf) 
Table 1. Results of GLM on concentrations (ppm) of copper, zinc and arsenic in eggshells of rook Corvus frugilegus from breeding colonies located in villages $(n=29)$ and towns $(n=14)$ and in areas of intensive (West; $n=28$ ) and extensive agriculture (East; $n=15$ ) in Poland.

\begin{tabular}{|c|c|c|c|c|c|c|}
\hline \multirow{2}{*}{ Metal } & \multicolumn{4}{|l|}{ Concentration } & \multicolumn{2}{|l|}{ GLM } \\
\hline & average ( $\pm 95 \%$ c.l. $)$ & $\min -\max$ & average ( $\pm 95 \%$ c.l.) & $\min -\max$ & $\begin{array}{ll}F \\
\end{array}$ & $P$-value \\
\hline & Villages & & Towns & & & \\
\hline $\mathrm{Cu}$ & $2.74(2.36-3.12)$ & $1.67-7.21$ & $19.31(4.57-43.20)$ & $1.93-150.45$ & 9.772 & 0.002 \\
\hline $\mathrm{Zn}$ & $11.94(4.23-19.64)$ & $1.98-113.53$ & $17.77(8.60-26.73)$ & $2.64-59.58$ & 1.741 & 0.190 \\
\hline \multirow[t]{2}{*}{ As } & $35.32(26.09-44.55)$ & $2.45-87.30$ & $26.86(16.26-37.47)$ & $3.40-58.06$ & 2.703 & 0.104 \\
\hline & West & & East & & & \\
\hline $\mathrm{Cu}$ & $11.02(0.58-22.63)$ & $1.67-150.45$ & $2.74(2.49-3.00)$ & $2.08-3.48$ & 2.320 & 0.131 \\
\hline $\mathrm{Zn}$ & $16.52(7.72-25.31)$ & $2.55-113.53$ & $8.75(5.36-12.13)$ & $1.98-20.16$ & 3.377 & 0.070 \\
\hline As & $30.94(22.77-39.12)$ & $30.40-80.49$ & $35.6(21.30-49.90)$ & $2.45-87.30$ & 0.829 & 0.365 \\
\hline
\end{tabular}


Appendix 1. Concentration (ppm) of copper, zinc and arsenic in eggshells of rook Corvus frugilegus from the surveyed breeding colonies in Poland; metal levels from two analyzed shells per colony are shown, respectively. ${ }^{1}$ Rookery numbers as in Fig. 1. ${ }^{2}$ Region (voivodship): D - dolnośląskie, L - lubuskie, Ś - śląskie, W - wielkopolskie, M mazowieckie, $\mathrm{P}$ - podlaskie. Three highest concentrations are marked in bold.

\begin{tabular}{|c|c|c|c|c|c|c|c|c|c|c|}
\hline \multirow[b]{2}{*}{$\mathrm{No}^{1}$} & \multirow[b]{2}{*}{ Location } & \multirow[b]{2}{*}{ Region $^{2}$} & \multicolumn{2}{|c|}{ Status of colony } & \multicolumn{6}{|c|}{ Metal level } \\
\hline & & & $\begin{array}{l}\text { village }(\mathrm{V}) / \\
\text { town }(\mathrm{T})\end{array}$ & $\begin{array}{l}\text { west (W) / } \\
\text { east }(E)\end{array}$ & $\mathrm{Cu}$ & & $\mathrm{Zn}$ & & As & \\
\hline 1 & Wrocław (1) & $\mathrm{D}$ & $\mathrm{T}$ & W & 2.84 & 2.84 & 35.68 & 52.51 & 7.92 & 7.00 \\
\hline 2 & Wrocław (2) & $\mathrm{D}$ & $\mathrm{T}$ & $\mathrm{W}$ & 4.67 & 4.89 & 3.97 & 6.21 & 3.64 & 3.16 \\
\hline 3 & Wrocław (3) & $\mathrm{D}$ & $\mathrm{T}$ & W & 60.92 & 70.29 & 9.31 & 12.73 & 9.893 & 9.695 \\
\hline 4 & Wrocław (4) & $\mathrm{D}$ & $\mathrm{T}$ & W & 150.24 & 150.66 & 15.53 & 16.81 & 33.78 & 33.41 \\
\hline 5 & Pietrzykowice & $\mathrm{D}$ & V & W & 2.91 & 2.83 & 10.62 & 15.41 & 26.99 & 24.62 \\
\hline 6 & Oleśnica & $\mathrm{D}$ & V & W & 2.76 & 2.74 & 2.94 & 4.58 & 37.17 & 34.95 \\
\hline 7 & Środa Śląska & $\mathrm{D}$ & $\mathrm{V}$ & $\mathrm{W}$ & 2.78 & 2.81 & 3.24 & 5.13 & 15.23 & 15.04 \\
\hline 8 & Przerzeczyn Zdrój & $\mathrm{D}$ & V & W & 1.85 & 1.80 & 1.97 & 3.13 & 28.69 & 25.61 \\
\hline 9 & Ząbkowice Śląskie & $\mathrm{D}$ & $\mathrm{V}$ & W & 3.76 & 3.71 & 15.59 & 21.66 & 39.25 & 33.89 \\
\hline 10 & Pszenno & $\mathrm{D}$ & V & W & 2.79 & 2.87 & 5.10 & 7.89 & 21.36 & 18.85 \\
\hline 11 & Borek Strzeliński & $\mathrm{D}$ & V & $\mathrm{W}$ & 1.70 & 1.64 & 2.04 & 3.25 & 30.87 & 27.59 \\
\hline 12 & Zgorzelec & $\mathrm{D}$ & $\mathrm{V}$ & W & 2.62 & 2.50 & 11.34 & 16.99 & 80.14 & 76.48 \\
\hline 13 & Zebrzydów & $\mathrm{D}$ & V & W & 7.60 & 6.82 & 117.96 & 109.10 & 11.73 & 13.15 \\
\hline 14 & Strzelin & $\mathrm{D}$ & V & W & 2.88 & 2.93 & 4.65 & 7.55 & 79.99 & 81.00 \\
\hline 15 & Łagiewniki & $\mathrm{D}$ & $\mathrm{V}$ & W & 2.58 & 2.55 & 5.20 & 8.49 & 37.16 & 33.10 \\
\hline 16 & Świdnica & $\mathrm{D}$ & $\mathrm{T}$ & $\mathrm{W}$ & 2.54 & 2.53 & 9.41 & 13.04 & 8.09 & 6.44 \\
\hline 17 & Głogów & $\mathrm{D}$ & $\mathrm{T}$ & W & 20.59 & 20.28 & 9.23 & 0.52 & 18.79 & 21.59 \\
\hline 18 & Gorzów Wlkp (1) & $\mathrm{L}$ & $\mathrm{T}$ & W & 2.15 & 2.11 & 55.17 & 64.00 & 49.86 & 52.73 \\
\hline 19 & Gorzów Wlkp (2) & $\mathrm{L}$ & $\mathrm{T}$ & W & 2.32 & 2.23 & 15.26 & 18.68 & 34.22 & 38.30 \\
\hline 20 & Wodzisław Śl. & Ś & $\mathrm{T}$ & $\mathrm{W}$ & 3.72 & 3.12 & 9.49 & 14.72 & 18.37 & 18.02 \\
\hline 21 & Gołębin Stary & W & V & W & 2.17 & 1.41 & 4.81 & 7.052 & 80.64 & 73.67 \\
\hline 22 & Żerków & $\mathrm{W}$ & $\mathrm{V}$ & W & 2.09 & 2.06 & 6.98 & 10.35 & 10.58 & 8.56 \\
\hline 23 & Kępno & W & V & W & 2.15 & 2.12 & 5.12 & 8.23 & 33.75 & 30.34 \\
\hline 24 & Laski & $\mathrm{W}$ & V & W & 1.93 & 1.88 & 3.43 & 5.64 & 34.76 & 31.65 \\
\hline 25 & Warszawa (1) & $\mathrm{M}$ & $\mathrm{T}$ & $\mathrm{W}$ & 5.01 & 4.51 & 15.42 & 25.33 & 53.12 & 61.70 \\
\hline 26 & Warszawa (2) & M & $\mathrm{T}$ & W & 3.24 & 3.24 & 7.38 & 11.65 & 23.51 & 26.81 \\
\hline 27 & Warszawa (3) & M & $\mathrm{T}$ & W & 2.01 & 1.86 & 12.54 & 17.58 & 24.16 & 27.72 \\
\hline 28 & Warszawa (4) & $\mathrm{M}$ & $\mathrm{T}$ & $\mathrm{W}$ & 2.74 & 2.54 & 15.03 & 22.21 & 20.38 & 23.81 \\
\hline 29 & Podnieśno & $\mathrm{P}$ & V & E & 3.21 & 3.23 & 3.50 & 5.50 & 15.82 & 12.21 \\
\hline 30 & Wyszków & $\mathrm{P}$ & V & $\mathrm{E}$ & 2.63 & 2.65 & 11.76 & 13.34 & 18.33 & 14.71 \\
\hline 31 & Iganie & $\mathrm{P}$ & V & E & 3.08 & 3.10 & 2.42 & 3.72 & 2.54 & 2.36 \\
\hline 32 & Biodry & $\mathrm{P}$ & V & E & 2.11 & 2.04 & 4.20 & 6.64 & 3.55 & 2.48 \\
\hline 33 & Żelków & $\mathrm{P}$ & V & $\mathrm{E}$ & 2.28 & 2.27 & 5.45 & 8.29 & 57.72 & 56.07 \\
\hline 34 & Czyżew & $P$ & V & E & 2.14 & 2.13 & 2.47 & 3.89 & 30.04 & 26.49 \\
\hline 35 & Zembrów & $\mathrm{P}$ & V & E & 2.44 & 2.39 & 1.59 & 2.36 & 23.41 & 18.97 \\
\hline 36 & Stoczek Łukowski & $\mathrm{P}$ & $\mathrm{V}$ & E & 2.14 & 2.09 & 5.62 & 8.62 & 39.23 & 35.34 \\
\hline 37 & Wizna & $\mathrm{P}$ & V & E & 3.02 & 3.06 & 4.52 & 7.38 & 46.67 & 43.67 \\
\hline 38 & Siedlce & $\mathrm{P}$ & $\mathrm{T}$ & E & 3.33 & 3.40 & 2.05 & 3.24 & 59.03 & 57.09 \\
\hline 39 & Oleśnica & $P$ & V & E & 2.87 & 2.92 & 9.78 & 12.60 & 78.49 & 80.20 \\
\hline 40 & Mokobody & $\mathrm{P}$ & V & E & 2.95 & 3.00 & 18.63 & 16.67 & 24.51 & 25.48 \\
\hline 41 & Seroczyn & $\mathrm{P}$ & $\mathrm{V}$ & E & 2.89 & 2.89 & 21.12 & 19.19 & 40.55 & 41.77 \\
\hline 42 & Mordy & $\mathrm{P}$ & V & $\mathrm{E}$ & 2.58 & 2.57 & 19.41 & 18.27 & 87.36 & 87.25 \\
\hline 43 & Toczyska & $\mathrm{P}$ & $\mathrm{V}$ & E & 3.45 & 3.51 & 8.03 & 12.13 & 19.97 & 16.66 \\
\hline
\end{tabular}




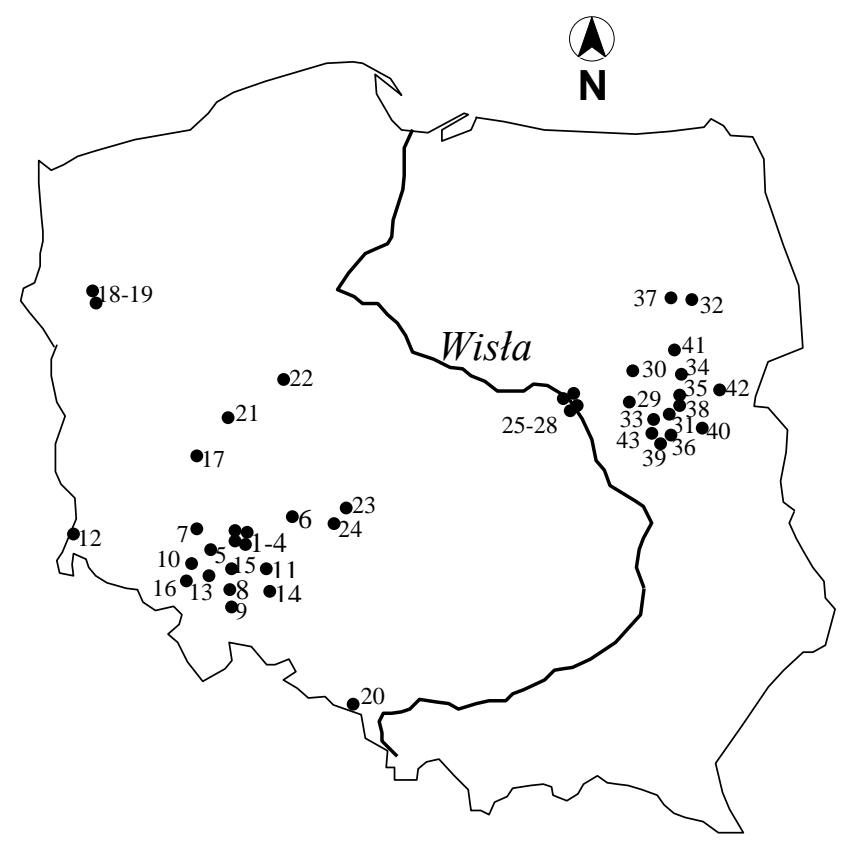

Fig. 1. Distribution of breeding colonies of the rook Corvus frugilegus in Poland, where the levels of copper, zinc and arsenic in the eggshells were surveyed. Rookeries numbered as in Appendix 1. The river of Wisła (Vistula) is the border between western and eastern Poland (= intensive vs extensive agriculture; see chapter Material and methods). 